\title{
Standardizing Diversity: Analysing Discursive Practice in Corporate Sustainability Narrative Disclosures
}

\author{
Arthik Davianti ${ }^{1}$ \\ $\left\{\right.$ arthik.davianti@uksw.edu $\left.{ }^{1}\right\}$ \\ Department of Accounting, Faculty of Economics and Business \\ Universitas Kristen Satya Wacana ${ }^{1}$
}

\begin{abstract}
This study is aimed to obtain preliminary observations and exploration of the standardization in the corporate sustainability practice, notably its reporting practice. The focus of information presented in the form of narrative disclosure set on diversity issues, as part of SDGs. The data was collected from the GRI Database of sustainability reports, as the case company. The study implemented intertextuality approach from Fairclough's meso level of CDA. The approach suggested textual dialogues, as presented by the case company were mainly related to the standards of disclosures despite the characteristics of diversity.
\end{abstract}

Keywords: diversity, corporate sustainability, narrative disclosures, intertextuality

\section{Introduction}

Textual discourse, as presented in the extensive corporate narrative disclosures, has become a representation of corporate action, particularly concerning sustainability issues. The issues comprise economic, social, and environmental aspects as the pillars of implementing the concept of sustainable development through sustainability practice. In the course of upholding the pillars, the social aspect has been the principal disclosed element presented by the corporation. Global Reporting Initiatives (GRI) has been the front runner for providing guidelines, which later became standard on reporting sustainability practice. GRI cooperates diversity as one of the social disclosure requirements in the corporate sustainability disclosures, which means the inclusion of diversity in corporate sustainability actions is an essential aspect of social-based arrangements. The disclosures practice itself would probably be presented in the form of narrative disclosures. Accordingly, the narrative disclosures concerning diversity stipulate a discourse about diversity as part of their sustainability practice based on the suggested GRI Standards.

Sustainable development has become undeniably important information to publish through disclosures. Disclosure on sustainable development issue would be classified on the theme of the information disclosed. The items are divided into disclosures on environmental concern, disclosures on people's involvement, disclosure on an economic aspect about sustainable development, and finally, disclosure on sustainability as a comprehensive approach towards sustainable development. Global Reporting Initiative (GRI) has been the front runner in standardizing reporting practice for the implementation of sustainable development or sustainability practice by corporation around the world. As per 2016, the GRI publish the GRI Standards as the new version of the previously G3 and G4 Guidelines to Sustainability Reporting. The Standards comprise standardized disclosure elements for the economic, social, and environmental aspect of corporate actions. Corporate sustainability practice based on the Standard also grounded on Management Approaches structured by companies in implementing corporate sustainability concepts to obtain harmony for there pillars of sustainable development.

Sustainable development, both conceptually and in practice, guides efforts to balance the economic, environmental, and social elements of development. The perspective of sustainability used in this study is based on a series of crucial UN documents. Utilizing these documents as a general foundation was important, as it provided a basis from which to analyze ideology and hegemonic struggle. From a historical perspective, sustainable development has been a recurring aspect of the UN's significant ongoing commitments. However, there are questions with regard to definitions of sustainable development [2-5], and the strategies to implement sustainability that occur at both conceptual and practical levels [6-10]. These could be interpreted as a broader ideological and hegemonic struggle over sustainable development. The foreseeable conceptual struggle, to a certain extent, was captured in the process of standardizing the practice of corporate sustainability.

In the recent elaboration of corporate sustainability practice, the global 2030 Agenda of Sustainability Development Goals (SDGs) has been one of the drivers for the practice, since 2015. The Agenda acknowledges the essential role of culture, creativity, and cultural diversity in reconciling the economic and social aspects of 
development, advancing economic growth, and fostering social inclusion. Thus, prioritizing diversity and inclusion develop into the improvement of corporate sustainability practice. The challenge would be on the role of standards in the implementation of sustainable development related issues for corporations, which also contribute to the demand for more disclosures related to achieving SDGs. In addition, with the increasing standardization of corporate sustainability reporting, the enclosure of diversity could lead to a process of standardizing diversity for companies. The process might create a paradox of standardizing issues of diversity, which could also indicate standardization for the existing diverse perspectives and practices.

Narrative accounting disclosures and the language used therein constitute a form of representation regarded as a construct of social facts or reality [11]. This study is based on the epistemology of social constructionism, such that "meanings are constructed by human beings as they engage with the world they are interpreting" [12]. Hence, social constructionism explains that epistemologically, the meaning is actively constructed by people, rather than merely discovered [12]. Crotty [12] notes that this theory of knowledge should be interpreted from a social perspective, in order to elucidate the process of understanding in a "world of meaning" where "all reality, as meaningful reality, is socially constructed" [12]; that is generated by human social interaction (p. 58). In the context of an examination of the human production of meaning in particular contexts such as those undertaken in this study, social constructionist epistemology is therefore appropriate. Shotter and Gergen [1994, p. i in 13] noted that social constructionism has:

given voice to a range of new topics, such as the social construction of personal identities; the role of power in the social making of meanings; rhetoric and narrative in establishing sciences; the centrality of everyday activities; remembering and forgetting as socially constituted activities; reflexivity in method and theorizing. The common thread underlying all these topics is a concern with the processes by which human abilities, experiences, common sense, and scientific knowledge are both produced in, and reproduce human communities.

Through interpretation and reinterpretation, social reality is transformed into a meaningful discourse [12]. Thus, such discourse also reflects a socially constructed understanding that creates interconnected relationships. This thesis is founded on the understanding that the narratives produced via interpretation and reinterpretation are extensively embedded with meaning, and that the particular form and characteristics of language play a significant role in the construction of the meanings transmitted through discourse.

The study focused on the corporate narrative sustainability disclosures as presented in the sustainability report uploaded by companies in the GRI Report Database, by focusing on enhancing the chances of cooperation within an organization. The database provides a wide range of sustainability reports published by companies across the world. Despite the quantitative measure of diversity within an organization, corporations include diversity practice related disclosures in the form of narrative disclosures. The intertextuality analysis revealed that in the narrative disclosures, corporations were not only lacking depiction of quantitative comparison on diversity amongst diversity categories but also presented limited textual dialogues in the narratives. Further investigation is required to obtain a comprehensive understanding of how diversity is represented in the disclosures.

Based on Fairclough's [1] Critical Discourse Analysis (CDA), the language used in the narrative disclosures exhibits discourse in three levels, micro-level - discourse as text, meso level - discourse as a discursive practice, and macro-level - discourse as a social practice. In the meso level, a discursive practice is analyzed through intertextuality based concept. The analysis of discursive practices provides descriptions of the textual dialogues embedded in the narrative accounting disclosures, which can reveal not only the inclusion of other texts but also organizations, notably, that produced those texts. The study sought to explore corporate sustainability narrative disclosures as the setting for textual discourse. The objective is to obtain an empirical indication as to what extent the intertextuality process is embedded in corporate sustainability narrative disclosures.

\section{Research Method}

This paper is a segment of a study of narrative accounting disclosures as presented in the reports submitted to the Global Reporting Initiative (GRI) Database. The study is still in the early stage of data collection and preliminary analysis for one of the cases in the main study. The focus would be on one of Indonesian company that continuously submitted their sustainability report to the GRI.

\subsection{Intertextuality in Fairclough's Critical Discourse Analysis}


CDA is directed towards the analysis of the use of language as a social practice, whereby dialogues occur between events, dynamics of social interactions, and discourse components that include representation, interaction, and tension. Thus, as a social practice, language use in events creates dialogues. Blommaert [26] concluded, among other things, that CDA emphasized that discourse is “... an instrument of power, of increasing importance in contemporary societies". Building on this understanding, Rogers [27] stated that the "critical" component of CDA could be interpreted as "... an attempt to describe, interpret, and explain the relationship between the form and function of language". In part, CDA is critical because it strives to identify social problems and solutions to those problems. Rogers also explained that the application of CDA is intended to "... uncover power relationships and demonstrate inequities embedded in society [27]. In identifying discourse as a powerful tool, Blommaert [26] argues that CDA aims to make the way discourse works "... more visible and transparent".

CDA assumes that language is part of the social process [28] and that the context of the use of language influences the process of understanding the use of texts [29]. The use of texts includes not only the processes of production, distribution, and consumption of text, but also the relationships between texts, social structure, and ideological and hegemonic struggles. Thus, with reference to these processes, Fairclough [1], also Fairclough [30], [31-33], proposed a critical approach to discourse analysis incorporating the three-dimensional conception of the levels of discourse, Figure 1.

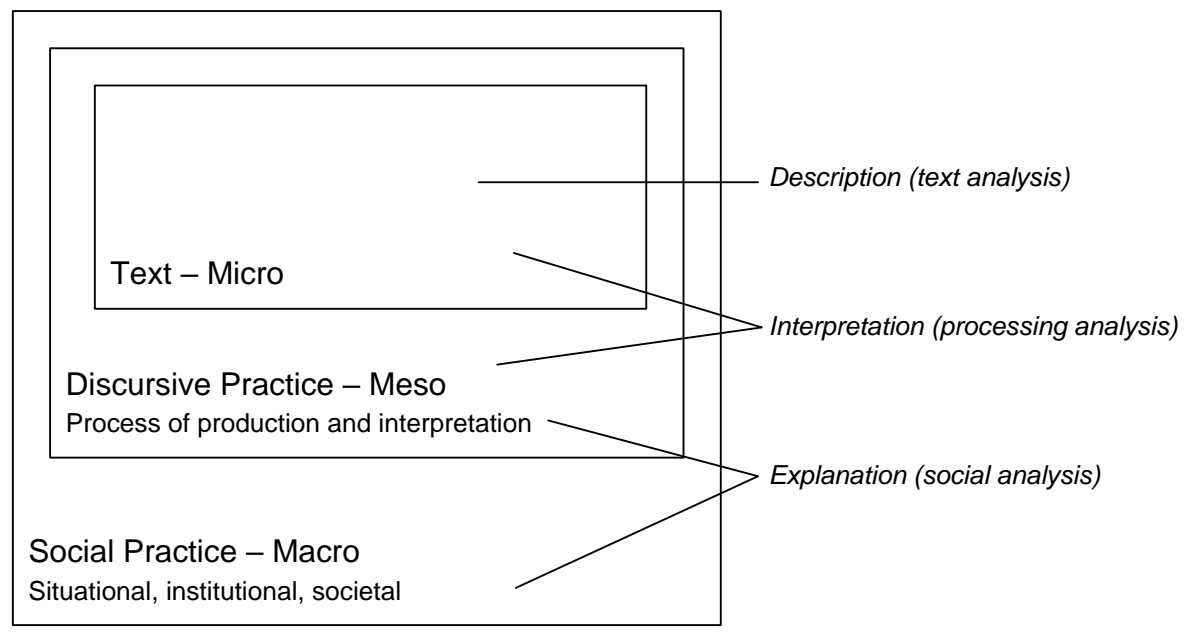

Fig. 1. Three-dimensional conception of discourse (adapted from Fairclough [30] [1] [33]; see also Koller [34])

The discursive practice involves social relationships, both as objects and subjects [1], which influence the processes of text production, distribution, and consumption [35]. Significant elements of discursive practice include the production and interpretation of text [1] and, due to differences between discourses arising from differing social factors, the processes used in discursive practices vary, to include text production, distribution, and consumption [1]. The meso dimension of CDA plays the role of bridging the micro and macro dimensions, including the concepts of intertextuality and interdiscursivity which help to reveal the strategies of both speakers and writers.

With the intention of emphasizing the significance of the discursive practice, Fairclough [1] used the Foucauldian phrase "orders of discourse" to refer to the entire spectrum of discursive practices within an institution, and even more widely, a society, and the relationships between them. Notably, however, Fairclough [36] described it somewhat more narrowly, as "... the ordered set of discursive practices associated with a particular social domain or institution". Subsequently, Fairclough [31] used a decidedly different slant with reference to orders of discourse, stating that it involved "... the social organization and control of linguistic variation". The "all-encompassing" interpretation initially suggested by Fairclough, however, is so broad that it could be considered almost meaningless; a theoretical construct that primarily encompasses almost all forms of communication could be construed as merely a slightly abstract definition of the word "communication" [31].

Blackledge [37] interpreted "orders of discourse" to mean "... the particular conventionalized practices which are available to text producers in particular circumstances". This interpretation is arguably the most useful in the context of facilitating research. Irrespective of the variation in literary interpretations of orders of discourse, the essential factor to recognize is that discourse is generated under various influences and that any given discourse is related to other discourses. 
The concept of intertextuality, as used in CDA, is based on Kristeva's (1986) terminology for textual dialogue [1]. Kristeva [38] brought more extensive attention to the concept of intertextuality, which was first introduced in the 1960s, by publishing Bakhtin's (1986) work in the 1950s on 'dialogism.' In the context of the communicative functions of language, Bakhtin [39] argued that “... all utterances, both spoken and written ... are demarcated by a change of speaker (or writer), and oriented retrospectively to the utterances of previous speakers ... and prospectively to the anticipated utterances of the next speakers".

Fairclough's [1] adaptation of intertextuality included two concepts: "manifest intertextuality" and "interdiscursivity." Manifest intertextuality is a condition where texts are composed of other specific texts. Thus, manifest intertextuality is defined as "... the explicit presence of other texts in a text" [1]. Most texts tend to be related to other texts because generally, new texts are created based on the knowledge and experience that people derive from other texts [40]. Therefore, manifest intertextuality is common. Fairclough [31] argued that texts "... set up dialogical or polemical relations between their 'own' discourses and the discourses of others". Based on Fairclough's interpretation of orders of discourse, intertextuality is described as the property most texts tend to have - is comprised of a combination of numerous other texts $[1,41]$.

Interdiscursivity, on the other hand, is "... the constitution of a text from a configuration of text types or discourse conventions" [1]. It refers to "... the intertextual relation of genres and discourses within a text" [37], where the genre is defined as "a way of acting and interacting linguistically" that "structures texts in a specific way" [31]. A genre that is textually related to another genre is considered to be in an interdiscursive relationship, and genres may both proceed and follow other genres in a chain [31]. This relationship denotes the links between discourses [42], such as the links between topic related perspectives, where one topic refers to another topic. For example, this study considers that the broad topic of 'sustainability' relates to the environmental, social, and economics subtopics.

The analysis is based on the meso level in Fairclough's CDA and focusing on intertextuality feature of discursive practice. This study explored to what extent the strategy corporation implemented in disseminating sustainability-related actions through narrative disclosures and whether textual dialogues presented in the narratives indicate the direction of the dialogues. The concept of intertextuality relates to how texts draw upon and incorporate the dialogue in other texts. In general terms, the analysis of textual dialogues is based on the use of intertextual representation techniques, including levels of intertextuality that capture dimensions and representations. These levels reflect the different ways in which a text could explicitly draw on, and adapt, to a greater or lesser extent, the logic of other texts.

\subsection{Data and Collection Process}

The corpus building procedure, used to construct a textual corpus, comprises the complete collection of writings of the same nature and related to one another [43]. This procedure is a cyclic process, beginning with the selection of a small, relevant, and homogeneous corpus, followed by an analysis of this corpus, then further corpus selection [43]. For this study, the selection of a relevant and homogenous corpus was initiated by identifying companies that submitted their sustainability reports on the GRI Database with diversity-related content in the reports. The sustainability report was selected and downloaded from the database https://database.globalreporting.org/. The GRI Database contains 13,903 organizations, 54,922 reports with 32,779 GRI based reports.

\subsection{Analysis Techniques}

Intertextuality focuses on textual dialogues that exemplify interactions between recently generated texts and pre-existing texts. Fairclough $[31$ p.39] referred to this phenomenon as "intertextuality," whereby the voices of others (that is, from previous texts) are potentially present in subsequent texts. Further, he proposed that these voices might be related through "dialogicality" of a text: “... the dialogue between the voice of the author of a text and other voices" [31 p.41].

Further, intertextual representation techniques may also be identified in the form of particular procedures used to represent words and inferences from other texts. Bazerman [40 pp.88-89] proposed six techniques that could indicate intertextuality:

a. Direct quotation. This is the most overtly explicit technique and is usually identified by the use of quotation marks, block indentation, italics, or other distinguishing forms of punctuation.

b. Indirect quotation. This usually specifies a source and then attempts to reproduce the meaning of the original statement, but in words that reflect an author's understanding, interpretation or "spin" on the original statement (including paraphrasing).

c. Mention of a person, documents, or statements. Mentioning a document or author relies on the reader's familiarity with the original material. In some cases, in order to capture the full breadth of intertextuality in 
this regard, the concept of mentioning a particular document or author in texts was broadened to include the mentions of particular organizations.

d. Comment on, or evaluation of, a statement, text, or other invoked voice.

e. Use of recognizable phrasing or terminology associated with specific people, groups of people, or particular documents.

f. Use of language that echoes particular ways of communicating, discussing among other people, or types of documents, such as identifiable genres, kinds of vocabulary, stock phrases, and patterns of expression.

This study, as a preliminary investigation, explores possible the intertextuality techniques as investigated from the narrative accounting disclosures. The case company is MedcoEnergy, an Indonesian energy company which has submitted its 2018 Sustainability Report to the GRI with a statement of compliance to the GRI Standards. MedcoEnergy operates not only in Indonesia but also in other countries, such as the United States of America, Tunisia, Yaman, Oman, and Libia. The study investigated the standardization of diversity as presented in MedcoEnergy Sustainability Report 2018.

\section{Preliminary Results and Discussion}

Studies on corporate sustainability issues have explored by investigating the factors or determinants that drive companies to disclose this particular type of information, studies of Al-Tuwaijri, Christensen [14], Cho, Patten [15], Gray, Javad [16], Clarkson, Li [17], Brammer and Pavelin [18], Aerts, Cormier [19], Cowan and Deegan [20], Magness [21], Campbell, Moore [22], Cormier, Magnan [23], Gao, Heravi [24], Buhr [25]. These studies revealed evidence that type of industry, environmental performance, public legitimacy, public pressure. They are then followed by studies on the content of the disclosures on corporate sustainability issues, such as content analysis on environmental and social disclosure, especially communication in a sustainability report and corporate social responsibility report. These studies emphasized the importance of reports as the form of communication regarding sustainability issues. Accordingly, the investigation conducted in this study provides a different perspectice by focusing on the meaning of the disclosures from the discourse perspective, particularly a critical approach to discourse.

The results as it is a preliminary exploration of possible intertextuality techniques would be presented based on the techniques which then followed by a narrative quotation of the disclosures presented in the MedcoEnergy Sustainability Report 2018. The exploration of the report suggested that the textual dialogues indicated standardized influence on the narrative accounting disclosures. It is most likely because the choice the MedcoEnergy made to comply with the GRI Standard, although the level of disclosures was partly due to the unavailability for minority and other vulnerability groups information. These findings revealed evidence on the use of non-mandatory standard as the ground of disclosing information on diversity [44]. Accordingly, the textual dialogues, as presented in the disclosures, indicated the significance of non-mandatory guidelines or standard in presenting information regarding diversity [45].

The following results show the intertextuality - textual dialogues - obtained from the narrative.

\section{$\underline{\text { Indirect quotation }}$}

As part of this process, MedcoEnergi and BSR compiled a comprehensive set of environmental, social, and governance (ESG) issues potentially relevant to our operations. This list of issues was developed in reference to the Global Reporting Initiative (GRI) sustainability reporting standards, the Sustainability Accounting Standards Board (SASB), the UN Sustainable Development Goals (SDGs), and BSR's experience and insights on sustainability issues in the energy and extractives sectors. (MedcoEnergy SR 2018, p.10) [emphasis added]

Diversity: Establish MedcoEnergi policy related to diversity and anti-discrimination in compliance with

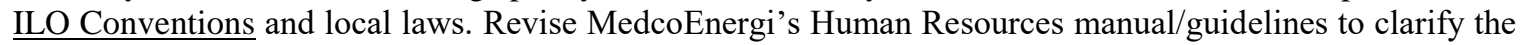
company's standards and expectations on diversity and anti-discrimination. Set diversity-related targets to ensure (MedcoEnergy SR 2018, p.25) [emphasis added]

GRI 405: Diversity and Equal Opportunity, 405-1 Diversity of governance bodies and employees, Information unavailable for minority or other vulnerable groups (MedcoEnergy SR 2018, p.69) [emphasis added]

The indirect quotation revealed standards and organizations referred by MedcoEnergy, such as GRI Standards, UN SDGs, also the SASB, an organization that organized the GRI Standards. Next, ILO Conventions were presented as the basis of diversity and anti-discrimination rules. The narrative mentioned local laws, but it was not specified, as to items of local laws specification. The company's standards seemed to be a clear basis 
for achieving diversity targets. However, similar to local laws, the narrative disclosures did not present nor explained the standards. Lastly, as the GRI Standard was set to be the foundation, the report stated the compliance towards was partly because of the unavailability of information regarding minority group or other vulnerable groups.

\section{$\underline{\text { Mention of statements }}$}

Our Objectives Diversity: We are committed to provide equal opportunities for employment regardless of their backgrounds. All employees are recruited, provided with career advancement and remuneration on the basis of job requirements, individual performance, and competence. Inclusion: We have the policy to hire and develop indigenous and local people. (MedcoEnergy SR 2018, p.21) [emphasis added]

Our sustainability goals and progress are enabled by a growing level of awareness of governments and communities about climate change, pollution, and the need for environmental protection, as well as increasing awareness of the responsibilities of companies to develop the workforce with commitments to open communication, high ethical standards, and diversity and inclusion-all of which we see as positive developments. (MedcoEnergy SR 2018, p.3) [emphasis added]

The narrative mentioned other statements, such as the company policies, the high ethical standards to assess positive developments that included diversity and inclusion. The policies were either implicitly or explicitly presented to include diversity and the description of inclusion as part of development, also the company identity [46].

\section{$\underline{\text { Recognizable phrasing }}$}

Analysis of stakeholder insights revealed significant commonalities on priority issues for MedcoEnergi, including business ethics, integrity and transparency, diversity and inclusion, talent recruitment and retention, and local community engagement, among others. (MedcoEnergy SR 2018, p.10) [emphasis added]

Our people are our most valuable asset - they are the keystone of our operations and our future success. We recruit diverse talent from all backgrounds who possess the right skillsets and ethical values. We are committed to maintaining a healthy and safe working environment built upon a culture of mutual respect. (MedcoEnergy SR 2018, p.21) [emphasis added]

Recruitment Gender diversity is an area where we would like to improve, especially at the senior manager level. In 2017, 85\% of our employees were male. (MedcoEnergy SR 2018, p.22) [emphasis added]

There is some level of subjectivity in exploring recognizable phrasing. This study focused on the phrases that consist of terms such as diversity, inclusion, diverse talent, mutual respect, and gender diversity. This phrasing is considered to be the phrase that would generally be associated with diversity issues. These phrases indicate a dialectical relation between the company and the expression in relation to diversity [47].

The narrative accounting disclosures explored and investigated on its intertextually basically is limited to the level of the disclosures presented by MedcoEnergy. Therefore, further exploration revealed an image that was stated to represent diverse talents. The figure showes a female working in hijab, which considered to be not conventional in MedcoEnergy. The reason is that most of MedcoEnergy workers are male, as shown in Figure 2 and Figure 3.

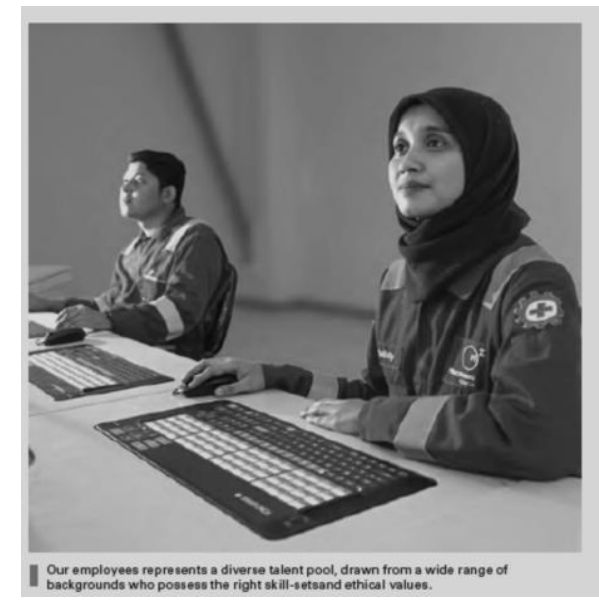

Fig. 2. Diverse Talent 


\begin{tabular}{|c|c|c|c|c|c|c|c|c|}
\hline $\begin{array}{l}\text { GRI } \\
\text { Standard } \\
\text { Number }\end{array}$ & $\begin{array}{l}\text { GRI Standard } \\
\text { Title }\end{array}$ & $\begin{array}{c}\text { Disclosure } \\
\text { Title }\end{array}$ & \multicolumn{2}{|c|}{ Individual Disclosure Items } & 2014 & 2015 & 2016 & 2017 \\
\hline \multirow[t]{12}{*}{ GRI 405-1 } & \multirow{12}{*}{$\begin{array}{c}\text { Diversity } \\
\text { and Equal } \\
\text { Opportunity }\end{array}$} & \multirow{12}{*}{$\begin{array}{l}\text { Diversity of } \\
\text { governance } \\
\text { bodies and } \\
\text { employees }\end{array}$} & \multirow{2}{*}{$\begin{array}{l}\text { a. Percentage of individuals within the } \\
\text { organization's governance bodies } \\
\text { in each of the following diversity } \\
\text { categories: } \\
\text { i. Gender }\end{array}$} & Female & $20 \%$ & $6 \%$ & $6 \%$ & $8 \%$ \\
\hline & & & & Male & $80 \%$ & $94 \%$ & $94 \%$ & $92 \%$ \\
\hline & & & \multirow[t]{3}{*}{ ii.Age group } & Under 30 years old & 0 & 0 & 0 & 0 \\
\hline & & & & $30-50$ years old & $40 \%$ & $42 \%$ & $43 \%$ & $50 \%$ \\
\hline & & & & Over 50 years old & $60 \%$ & $58 \%$ & $57 \%$ & $50 \%$ \\
\hline & & & \multicolumn{2}{|c|}{$\begin{array}{l}\text { iii.Other indicators of diversity where relevant (such as } \\
\text { minority or vulnerable groups). }\end{array}$} & & \multicolumn{2}{|c|}{ Not available } & \\
\hline & & & \multirow{2}{*}{$\begin{array}{l}\text { b. Percentage of employees per employee } \\
\text { category in each of the following } \\
\text { diversity categories: } \\
\text { i. Gender }\end{array}$} & Female & $17 \%$ & $16 \%$ & $16 \%$ & $15 \%$ \\
\hline & & & & Male & $83 \%$ & $84 \%$ & $84 \%$ & $85 \%$ \\
\hline & & & \multirow[t]{3}{*}{ ii. Age group } & Under 30 years old & $21 \%$ & $17 \%$ & $16 \%$ & $17 \%$ \\
\hline & & & & 30-50 years old & $70 \%$ & $74 \%$ & $75 \%$ & $54 \%$ \\
\hline & & & & Over 50 years old & $8 \%$ & $8 \%$ & $9 \%$ & $29 \%$ \\
\hline & & & \multicolumn{3}{|c|}{$\begin{array}{l}\text { iii.Other indicators of diversity where relevant (such as } \\
\text { minority or vulnerable groups). }\end{array}$} & \multicolumn{2}{|c|}{ Not available } & \\
\hline
\end{tabular}

Fig. 3. Diversity and Equal Opportunity Table

\section{Conclusion}

The objective of this study is to obtain empirical indications as to what extent the intertextuality process is embedded in corporate sustainability narrative disclosures. The preliminary results showed that despite the existence of textual dialogues, the narrative accounting disclosures have the nature of a standardized form of information dissemination. These results indicated dialectical relations where different ideas interact within the disclosures. The standardization could lead to limited information concerning diversity, its importance, and implementation by the corporation. However, it is clear that this study nonetheless presented limited findings, which lead to the importance of further studies on standardizing diversity for companies, business entities. The introduction of critical discourse analysis, mainly based on Fairclough's framework, revealed a high implementation potential in investigating textual dialogues, especially within corporate narratives.

\section{Reference}

[1]Fairclough, N., Discourse and Social Change. 1992, Cambridge, UK: Polity Press. 259.

[2]Hopwood, B., M. Mellor, and G. O'Brien, Sustainable development: mapping different approaches. Sustainable Development, 2005. 13(1): p. 38-52.

[3]Lélé, S.M., Sustainable Development: A Critical Review. World Development, 1991. 19(6): p. 607-621.

[4]Redclift, M., Sustainable development (1987-2005): an oxymoron comes of age. Sustainable Development, 2005. 13(4): p. 212-227.

[5]Imran, S., K. Alam, and N. Beaumont, Reinterpreting the Definition of Sustainable Development for a More Ecocentric Reorientation. Sustainable Development, 2011.

[6]Barkemeyer, R., et al., What Happened to the 'Development' in Sustainable Development? Business Guidelines Two Decades After Brundtland. Sustainable Development, 2011.

[7]Daly, H.E., Beyond Growth: the Economics of Sustainable Development. 1996, Boston :: Beacon Press.

[8]Drexhage, J. and D. Murphy, Sustainable Development: From Brundtland to Rio 2012. 2010, International Institute for Sustainable Development: New York.

[9]Mebratu, D., Sustainability and sustainable development: Historical and conceptual review. Environmental Impact Assessment Review, 1998. 18(6): p. 493-520.

[10]Sikdar, S.K., Sustainable development and sustainability metrics. AIChE Journal, 2003. 49(8): p. 1928-1932.

[11]Hines, R.D., Financial accounting: In communicating reality, we construct reality. Accounting, Organizations and Society, 1988. 13(3): p. 251-261.

[12]Crotty, M., The Foundation of Social Research: Meaning and Perspective in the Research Process. 1998, Sydney: Allen \& Unwin. 248.

[13]Potter, J., Discourse analysis and constructions approach: theoretical background, in Handbook of Qualitative Research Method for Psychology and the Social Sciences, J.T.E. Richardson, Editor. 1996, British Psychological Society: Leicester. p. 125-140.

[14]Al-Tuwaijri, S.A., T.E. Christensen, and K. Hughes, The relations among environmental disclosure, environmental performance, and economic performance: a simultaneous equations approach. Accounting, Organizations and Society, 2004. 29(5): p. 447-471. 
[15]Cho, C.H., D.M. Patten, and R.W. Roberts, Corporate political strategy: an examination of the relation between political expenditures, environmental performance, and environmental disclosure. Journal of Business Ethics, 2006. 67(2): p. $139-154$.

[16]Gray, R., et al., Social and environmental disclosure and corporate characteristics: a research note and extension. Journal of Business Finance \& Accounting, 2001. 28(3-4): p. 327-356.

[17]Clarkson, P.M., et al., Revisiting the relation between environmental performance and environmental disclosure: An empirical analysis. Accounting, Organizations and Society, 2008. 33(4): p. 303-327.

[18]Brammer, S. and S. Pavelin, Factors influencing the quality of corporate environmental disclosure. Business Strategy and the Environment, 2008. 17(2): p. 120-136.

[19]Aerts, W., D. Cormier, and M. Magnan, Corporate environmental disclosure, financial markets and the media: An international perspective. Ecological Economics, 2008. 64(3): p. 643-659.

[20]Cowan, S. and C. Deegan, Corporate disclosure reactions to Australia's first national emission reporting scheme. Accounting \& Finance, 2011. 51(2): p. 409-436.

[21]Magness, V., Strategic posture, financial performance and environmental disclosure: an empirical test of legitimacy theory. Accounting, Auditing \& Accountability Journal, 2006. 19(4): p. 540-563.

[22]Campbell, D., G. Moore, and P. Shrives, Cross-sectional effects in community disclosure. Accounting, Auditing \& Accountability Journal, 2006. 19(1): p. 96-114.

[23]Cormier, D., M. Magnan, and B. Van Velthoven, Environmental disclosure quality in large German companies: economic incentives, public pressures or institutional conditions? European Accounting Review, 2005. 14(1): p. 3-39.

[24]Gao, S.S., S. Heravi, and J.Z. Xiao. Determinants of corporate social and environmental reporting in Hong Kong: a research note. in Accounting Forum. 2005. Elsevier.

[25]Buhr, N., Environmental performance, legislation and annual report disclosure: the case of acid rain and Falconbridge. Accounting, Auditing \& Accountability Journal, 1998. 11(2): p. 163-190.

[26]Blommaert, J., Discourse : A Critical Introduction. 2005, New York Cambridge University Press. xiii, 299 p. : ill.

[27]Rogers, R., An Introduction to Critical Discourse Analysis in Education, in An Introduction to Critical Discourse Analysis in Education, R. Rogers, Editor. 2004, Lawrence Erlbaum Associates, Inc.: New Jersey.

[28]Fairclough, N. and R. Wodak, eds. Critical Discourse Analysis. Discourse as Social Interaction, ed. T.A. Van Dijk. Vol. 2. 1997, SAGE: London. 258-284.

[29]Fairclough, N., ed. A Dialectical-relational Approach to Critical Discourse Analysis in Social Research. Second ed. Methods of Critical Discourse Analysis, ed. R. Wodak and M. Meyer. 2009, SAGE Publications Ltd: London. 204.

[30]Fairclough, N., Language and Power. 1989, Essex, England: Longman Group UK Limited.

[31]Fairclough, N., Analysing Discourse: Textual Analysis for Social Research. 2003, Oxon: Routledge.

[32]Fairclough, N., ed. Discourse, Social Theory, and Social Research. Discourse Studies, ed. T.A. van Dijk. Vol. 2. 2007, SAGE Publication Ltd: London. 229-257.

[33]Fairclough, N., Critical Discourse Analysis: The Critical Study of Language. 2nd ed. 2010, Harlow: Pearson Education Limited.

[34]Koller, V., How to Analyse Collective Identity in Discourse - Textual and Contextual Parameter. Critical Approaches to Discourse Analysis across Disciplines, 2012. 5(2): p. 19-38.

[35]Woodside-Jiron, H., Language, Power, and Participation: Using Critical Discourse Analysis to Make Sense of Public Policy, in An Introduction to Critical Discourse Analysis in Education, R. Rogers, Editor. 2004, Lawrence Erlbaum Associates, Inc.: New Jersey.

[36]Fairclough, N., Critical Discourse Analysis: The Critical Study of Language. 1995, London: Longman.

[37]Blackledge, A., Discourse and Power in a Multilingual World. 2005, Amsterdam: John Benjamins Pub.

[38]Kristeva, J., Word, dialogue and novel, in The Kristeva Reader, T. Moi, Editor. 1986, Basil Blackwell: Oxford.

[39]Bakhtin, M.M., Speech Genres and Other Late Essays, ed. C. Emerson and M. Holquist. 1986, Austin: University of Texas Press.

[40]Bazerman, C., Intertextuality: How Texts Rely on Other Texts, in What Writing Does and How It Does it: An Introduction to Analysing Texts and Textual Practices, C. Bazerman and P. Prior, Editors. 2004, Lawrence Erlbaum Associates, Inc., Publisher: New Jersey. p. 83-96.

[41]Bloor, M. and T. Bloor, The Practice of Critical Discourse Analysis: An Introduction. 2007, London: Hodder Education. [42]Reisigl, M. and R. Wodak, The Discourse -Historical Approach (DHA), in Methods of Critical Discourse Analysis, R. Wodak and M. Meyer, Editors. 2009, SAGE Publications Ltd: London. p. 87-121.

[43]Bauer, M.W. and B. Aarts, Corpus Construction: a Principle for Qualitative Data Collection, in Qualitative Researching with Text, Image and Sound, M.W. Bauer and G. Gaskel, Editors. 2000, SAGE Publications Ltd: London. p. 19-38.

[44]Polinsky, A.M. and S. Shavell, Mandatory versus voluntary disclosure of product risks. The Journal of Law, Economics, \& Organization, 2010. 28(2): p. 360-379.

[45]Warren, M., Realisations of Intertextuality, Interdiscursivity, in Discourse, communication and the enterprise: genre and trends, G. Garzone and G. Maurizio, Editors. 2011, Peter Lang: Bern; New York. p. 91-110.

[46]Battaglia, M., et al., Sustainability reporting and corporate identity: action research evidence in an Italian retailing cooperative. Business Ethics: A European Review, 2015. 24(1): p. 52-72.

[47]Fairclough, N., A Dialectical-relational Approach to Critical Discourse Analysis in Social Research, in Methods of Critical Discourse Analysis, R. Wodak and M. Meyer, Editors. 2007, SAGE Publications Ltd.: London. p. 204. 